\title{
Drinking Water Treatment: pH Adjustment Using Natural Physical Field
}

\author{
Hesham Mohamed Abdal-Salam Yehia, Said Mahmoud Said \\ Department of Biotechnology, HST Company, Cairo, Egypt \\ Email: hyehia@hlogicgroup.com
}

How to cite this paper: Yehia, H.M.A.-S. and Said, S.M. (2021) Drinking Water Treatment: $\mathrm{pH}$ Adjustment Using Natural Physical Field. Journal of Biosciences and Medicines, 9, 55-66. https://doi.org/10.4236/jbm.2021.96005

Received: May 4, 2021

Accepted: June 4, 2021

Published: June 7, 2021

Copyright $\odot 2021$ by author(s) and Scientific Research Publishing Inc. This work is licensed under the Creative Commons Attribution International License (CC BY 4.0).

http://creativecommons.org/licenses/by/4.0/

(c) (i) Open Access

\begin{abstract}
Water has a $\mathrm{pH}$ of around (7.0), making it neither alkaline nor acidic. Alkaline is defined as a $\mathrm{pH}$ value greater than (7.0). The power of water to neutralize acids is measured by its alkalinity. The $\mathrm{pH}$ scale ranges from $(\mathrm{pH}=0$ to 14$)$, with anything above $(\mathrm{pH}=7.0)$ being alkaline, and anything below (7.0) being acidic. Much of the research up to now has been investigating the effect of adding alkaline substances to the water to increase the $\mathrm{pH}$ levels. Recent evidence suggests that using baking soda (sodium bicarbonate), which is an alkaline substance with a $\mathrm{pH}$ of about (9). While studies have shown that adding soda to water increases its alkalinity, it has a number of negative health consequences. For instance, Hypokalemia, Hypochloremia, High levels of sodium in the blood, Worsening kidney disease, Worsening heart failure, Muscle weakness and spasm, and Increased stomach acid production. The main aim of this study is to investigate a natural substance consisting of environmental elements i.e., it is derived from silica by the thermal fusion method (prepared by the authors) that raises the $\mathrm{pH}$ of water with a physical field of $80 \mathrm{~cm}$ without adding any components to the water. The results showed the effectiveness of this natural substance in its solid and liquid forms in raising the $\mathrm{pH}$ of water to reach 8.5 from a distance range $=80 \mathrm{~cm}$, without any side effects on human health.
\end{abstract}

\section{Keywords}

Alkaline, Acidic, Water, pH Value, Biotechnology, Physical Field

\section{Introduction}

Water is known as a key component of the life of any living organism, but this source of life can be a curse in some cases and drinking water becomes a danger to people's health [1]. In details, Loss et al., 2017 explained a report published by 
the Soil and Tillage Research, a specialist in which they said that some people suffer from many health problems due to drinking water [2]. Their study report attributed these problems to the fact that many people do not realize the value of what is called the " $\mathrm{pH}$ " of the water they drink, as the $\mathrm{pH}$ determines the concentration of hydrogen ions in the water, which determines the "acidity" of the water, which can cause problems. Many if it is high or low, depending on the health condition. Researchers warn that a low $\mathrm{pH}$ turns water into a toxic solution, and it is also more attractive to heavy metals in the human body.

The $\mathrm{pH}$ is lower, may cause digestive problems for some people, if the person suffers from high acidity in the stomach. This explains the increase in the popularity of potable alkaline water in the recent period, which leads to the neutralization of acids in the digestive system, and makes the person feel more comfortable. Alkaline water helps the body become more alkaline, which treats many diseases including cancer [3] [4]. Also, drinking alkaline water leads to an equalization of the $\mathrm{pH}$ of the mouth, digestive system, and urine, so its continued intake leads to an equalization of the $\mathrm{pH}$ of the whole human body. In turn, a study indicated that the use of alkaline water with a degree of 8.8 can disrupt the work of an enzyme in the body, which plays a dangerous role in heartburn, and reduces its annoying symptoms. She explained that alkaline water, which has a $\mathrm{pH}$ between 8.5 and 10 degrees, is beneficial for people with irritable bowel syndrome. It is noteworthy that the human body has a "fine natural regulator" of acidity levels, which cause changes in the $\mathrm{pH}$ of the blood, such as that which solve serious problems in the organs and tissues [5].

\section{Literature Review}

The $\mathrm{pH}$ of water indicates whether it is acidic or alkaline. The $\mathrm{pH}$ scale ranges from 0 to 14 , with 7 indicating neutral. The $\mathrm{pH}$ of drinking water should be between 6 and 8.5. If the water is acidic, this treatment process is used (low $\mathrm{pH}$ ) [6]. When pumped into a water system, soda ash (sodium carbonate) and sodium hydroxide increase the $\mathrm{pH}$ of the water to near neutral. They do not cause hardness problems in treated water, unlike neutralizing filters [7]. Baking soda's $\mathrm{pH}$ cannot be measured since it is a dry powder. Since $\mathrm{pH}$ is determined by the relative amounts of free hydrogen and hydroxyl ions in a water-based solution, an aqueous solution is needed.

Researchers attempted to evaluate the impact of physically activated carbon to remove natural organic matter in drinking water purification process. Korotta-Gamage and Sathasivan (2017) highlighted that physically activated carbon (BAC) removes low molecular weight in natural organic matter (NOM). They also concluded that treatment with BAC is slow, and the effluent can contain soluble microbial products and microbes [8]. On the other hand, a great deal of previous research has focused on removing some compounds from the water, especially groundwater, in order to raise the $\mathrm{pH}$ of the water, making it alkaline. Bora and Dutta (2019) set up a series of experiments using a new technic to re- 
move of metals $(\mathrm{Pb}, \mathrm{Cd}, \mathrm{Cu}, \mathrm{Cr}, \mathrm{Ni}$, and $\mathrm{Co})$ from drinking water by oxidation-coagulation-absorption at optimized $\mathrm{pH}$. In fact, the removal of certain metals, such as $\mathrm{Cd}, \mathrm{Pb}, \mathrm{Ni}, \mathrm{Cr}, \mathrm{Cu}$, and $\mathrm{Co}$, from groundwater using the oxidation-coagulation-adsorption at optimised $\mathrm{pH}$ (OCOP) process, which is an effective and low-cost method for simultaneous removal of As, Fe, and Mn. In their study the process has been found to remove the selected metals from an initial concentration of $2 \mathrm{mg} / \mathrm{L}$ in the following order: Cd (79.0 percent), Co (94.8 percent), Ni (94.4 percent), $\mathrm{Cu}$ (98.0 percent), $\mathrm{Cr}$ (98.3 percent), and $\mathrm{Pb}$ (98.3 percent) (99.5 percent). The heavy metals adsorb on the surface of coagulates according to atomic adsorption spectrophotometer, energy distributed X-ray spectrophotometer, and powder X-ray diffraction analyses [9].

Hashim et al., (2019) demonstrated that the use of an electrocoagulation (EC) reactor with aluminium electrodes is used to investigate the effect of the initial $\mathrm{pH}$ on the removal of reactive black 5 dye (RB5) from water. In their study several sets of continuous flow experiments were started at five different initial $\mathrm{pH}$ values $(4,5,6,7$, and 8$)$ while keeping the current density, inter-electrode size, and RB5 concentration constant at $2 \mathrm{~mA} / \mathrm{cm}^{2}, 4 \mathrm{~mm}$, and $25 \mathrm{mg} / \mathrm{L}$, respectively. The most obvious finding to emerge from this study is that the removal efficiency increased steadily as the initial $\mathrm{pH}$ increased from 4 to 6 , reaching a maximum of $96 \%$ at the neutral $\mathrm{pH}$ range, before decreasing to $74 \%$ as the initial $\mathrm{pH}$ increased to $8 \mathrm{pH}$ value [10].

Not only drinking water needs to raise $\mathrm{pH}$ levels, but also fish farming water needs to raise $\mathrm{pH}$ levels, and this is what we find in a study by Martins et al., (2017) as sodium bicarbonate $\left(\mathrm{NaHCO}_{3}\right)$, calcium carbonate $\left(\mathrm{CaCO}_{3}\right)$, and calcium hydroxide $\left(\mathrm{Ca}(\mathrm{OH})_{2}\right)$ were used to test alkalinity and $\mathrm{pH}$ maintenance on BFT during a Nile tilapia (Oreochromis niloticus) nursery. The findings show that using sodium bicarbonate, hydroxide, or calcium carbonate to change alkalinity and $\mathrm{pH}$ in the final proportions of $14.64,0.49,7.18,0.32$, and $24.09,2.32$ percent in relation to feed consumption, respectively, is accurate [11].

It is now well established from a variety of studies it becomes clear to us beyond a reasonable doubt that there is no scientific study that has carried out the process of raising the $\mathrm{pH}$ in a physical field without chemical intervention. Therefore, this study tries to test the effect of the biosphere for heat treated silica under certain conditions in raising the $\mathrm{pH}$ of drinking water and helping to remove harmful bacteria in it.

\section{Research Methodology}

The amount of hydrogen ions present in water is measured by the $\mathrm{pH}$ of the water. It decides whether the water is acidic or alkaline. The term $\mathrm{pH}$ refers to the hydrogen potential. The $\mathrm{pH}$ of water should be between 6.5 and 8.5 , according to the World Health Organization (WHO). pH can be determined using the following formula: $\mathrm{pH}=-\log [\mathrm{H}]$. Experimentally, the water indicates that the number of $\mathrm{H}^{+}$and $\mathrm{OH}^{-}$ions is equal. It has also been established that the prod- 
uct of the two concentrations equals a constant ' $K$.' This constant's value was discovered to be between 10 and 14 .

$$
\mathrm{H}_{2} \mathrm{O} \rightarrow \mathrm{H}^{+}+\mathrm{OH}^{-} .
$$

As Figure 1 shown, $\mathrm{pH}$ ranges from 0 to 14, with 7 being neutral. pHs less than 7 are acidic while pHs greater than 7 are alkaline (basic).

\section{1. $\mathrm{Na}_{2} \mathrm{SiO}_{3}$ Sample}

The initial sample consisted of a natural material of silica $\mathrm{SiO}_{2}$ with a micro-thermal fusion technology, which works to generate a bio-field of up to $80 \mathrm{~cm}$. Our research is concentrating about the physical effect on oxonium ions in any matrix and thru this Field we make change into alkaline state due to the active bride which have been created between silica and sodium atoms. This contribution helping to raise the $\mathrm{pH}$ of water to up to 8 . In order to obtain a higher purity, more powerful acids such as hydrofluoric acid can be used in addition to thermal shocks. After the refining process the sand is dry, and some applications require it to be milled to produce very thin materials, called silica flour as depicted in Figure 2.

Quartz can also be converted to crystallite in a rotary kiln operating at elevated temperatures, with the inclusion of catalysts. Also, some applications require that quartz be melted in electric arc furnaces to be cooled and then milled to produce silica magma the results of this sample coined in Table 1.

\section{Evaluation Methodology and Results}

The solution was then assayed for increasing the $\mathrm{pH}$ value using the ASTM E70-Standard test method. This standard was applied for calibration of our instrument, and $\mathrm{pH}$ of aqueous solution measurement. The test environment was at $20^{\circ} \mathrm{C}, 73 \%$ humidity [12].

\subsection{Evaluation Procedure}

To assess whether the $\mathrm{pH}$ values are increased and received, the evaluation criteria

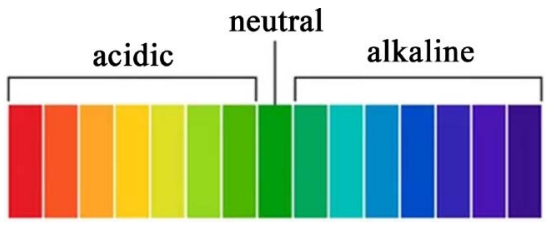

Figure 1. pH Scale.

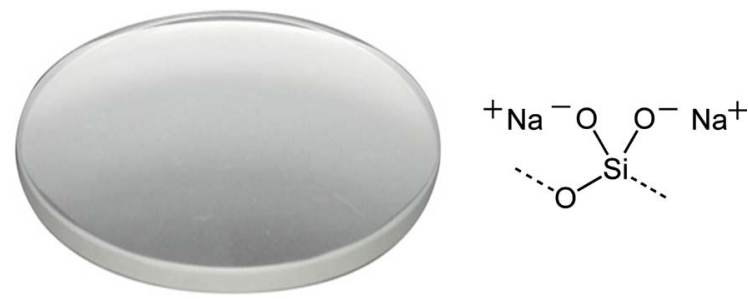

Figure 2. The forms of $\mathrm{Na}_{2} \mathrm{SiO}_{3}$ Sample used in this investigation. 
Table 1. Properties of $\mathrm{Na}_{2} \mathrm{SiO}_{3}$.

\begin{tabular}{cc}
\hline Name & $\mathrm{Na}_{2} \mathrm{SiO}_{3}$ Properties \\
\hline Also Known as & Silicon dioxide \\
Appearance & Silica, Silic acid and Silic acid anhydride \\
Molecular Formula & Transparent solid (amorphous) White (sand/powder) \\
Melting Point & $\mathrm{SiO}_{2}$ \\
Boiling Point & Around $1400^{\circ} \mathrm{C} 1700^{\circ} \mathrm{C}$ \\
Density & $2230^{\circ} \mathrm{C}$ \\
Molar Mass & $2.65 \mathrm{~g} / \mathrm{cm}^{3}(\alpha$-quartz) \\
$2.196 \mathrm{~g} / \mathrm{cm}^{3}($ amorphous $)$ \\
$60.08 \mathrm{~g} / \mathrm{mol}$
\end{tabular}

were as follows:

1) In a $100 \mathrm{~mL}$ beaker, $50 \mathrm{~mL}$ of tap water was put and sealed with a stretch cover.

2) Our $\mathrm{pH}$-meter was calibrated with buffers before each measurement of $\mathrm{pH}$ value (4, 7.02, and $10 \mathrm{pH}$ unit).

3) The water temperature was measured as well as the $\mathrm{pH}$ value.

4) The $100 \mathrm{~mL}$ beaker containing the $50 \mathrm{~mL}$ water was placed on the samples in Figure 2 to measure the effect of the physical field on raising the $\mathrm{pH}$ value.

5) The temperature of the water and the $\mathrm{pH}$ was measured every hour (The beaker is re-covered with stretch material after each measurement) without any interference in the water except that it is installed on the base that contains the manufactured material in this study, the result of this experiment is shown in Figure 3.

The experiment lasted about five hours. Both the temperature and the $\mathrm{pH}$ at the beginning and until the end of the experiment were measured accurately, as shown in Figure 3, to ensure the neutrality of the measurements was carried out through the National Institute for Standard in the Arab Republic of Egypt (Appendix A).

To ensure the validity of the results, the tests were repeated according to the previous conditions in the laboratories of the Drinking Water and Wastewater Authority, Egypt (Appendix B). The results showed that the $\mathrm{pH}$ levels increased by using the substance in a physical field, as shown in Figure 4.

Through the previous results, we find that the $\mathrm{pH}$ levels of water have increased from the neutral position 7 to the alkaline state 8 and this is through a vital field without direct intervention on the water, and these results are unique in the field of improving water quality, and they have direct applications on agriculture and improving the quality Drinking water and fish farming.

\subsection{Radiation Evaluation}

To indicate whether the manufactured material $\left(\mathrm{Silica} \mathrm{SiO}_{2}\right)$ contains radioactive or null elements. The evaluation method and procedures are summarized in Table 2. 
Time intervals (h)

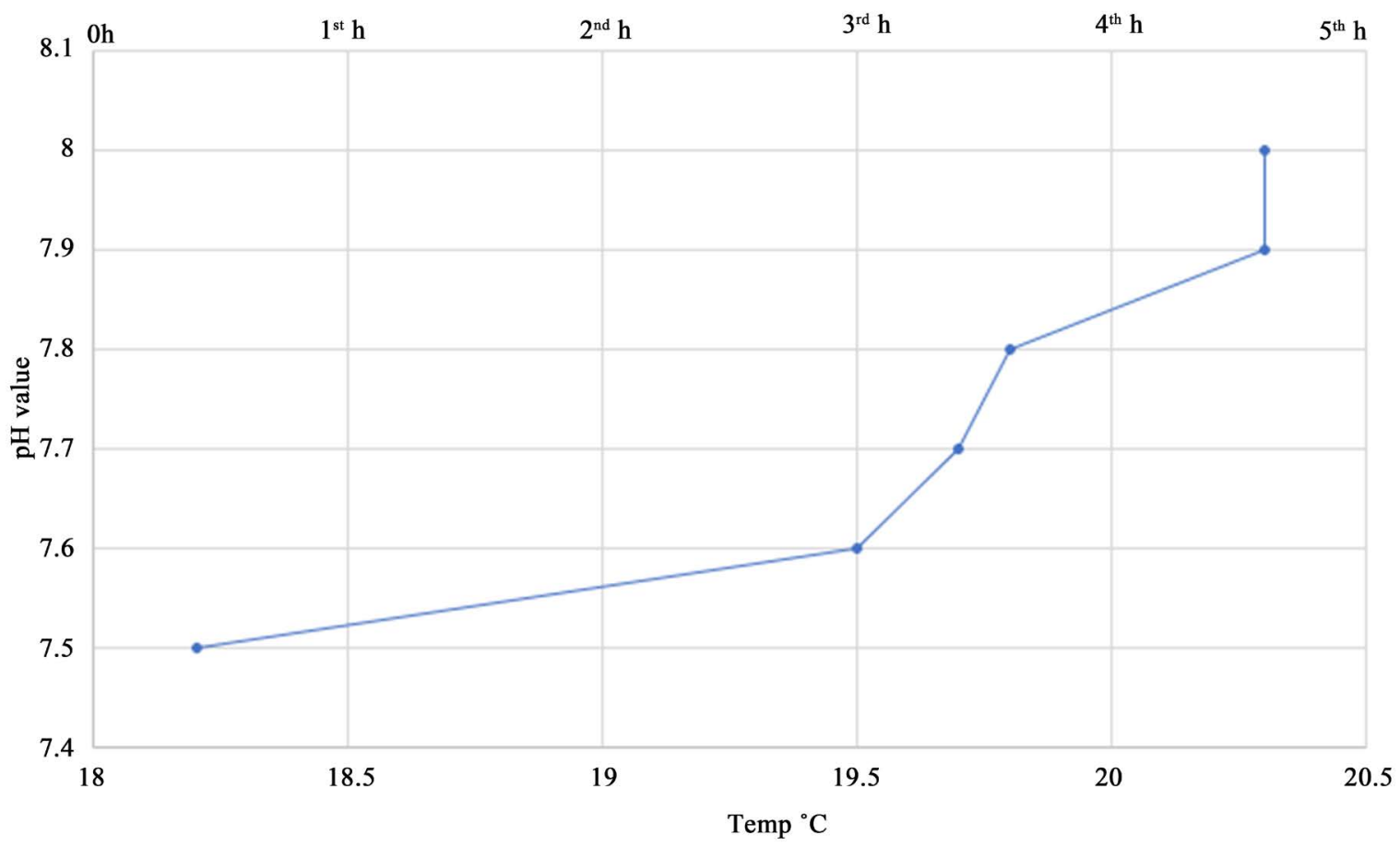

Figure 3. The results of the $\mathrm{pH}$ value over time (first experiment).

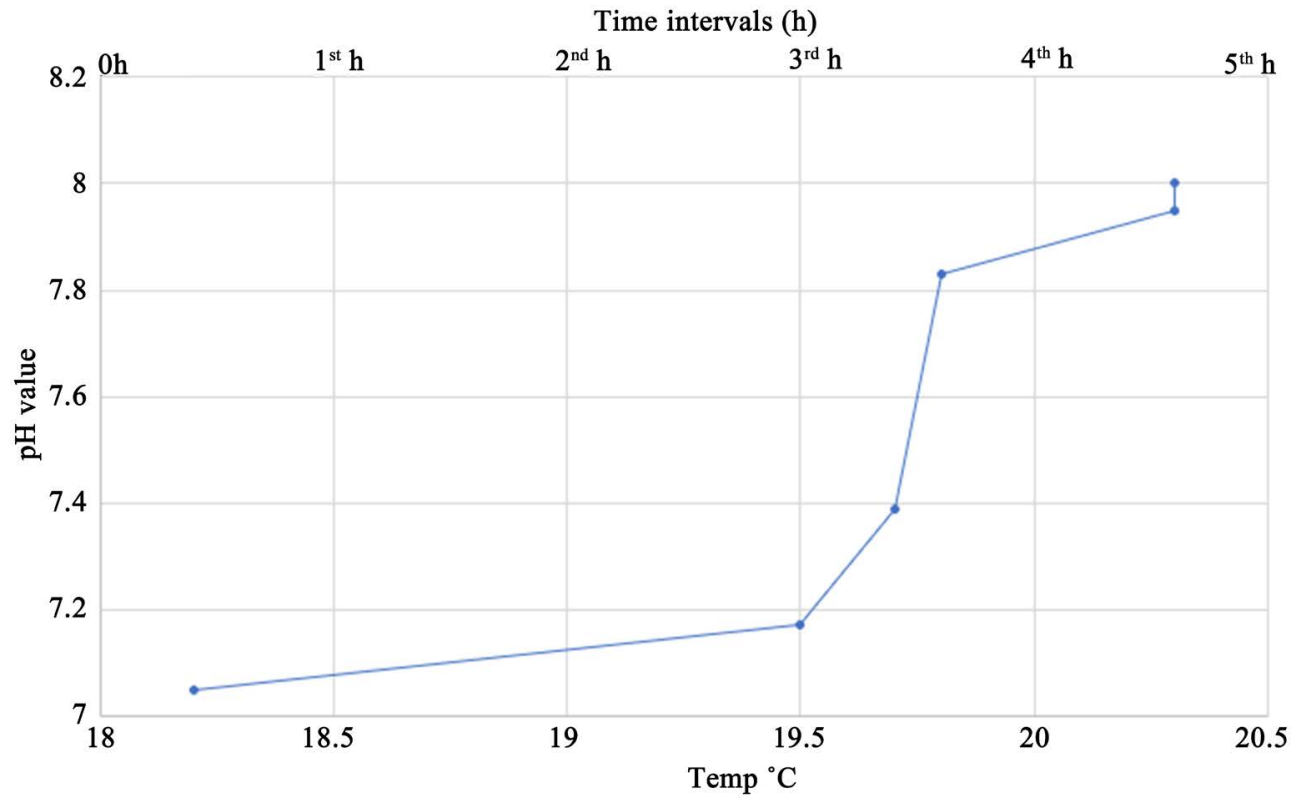

Figure 4.The results of the $\mathrm{pH}$ value over time (Second experiment).

Table 2. Radiation evaluation method and procedures.

\begin{tabular}{ccc}
\hline Device Name & Type & Manufacturer \\
\hline Detector & Nal (TI) Scintillation detector 3"*3” & Canberra \\
Analyzer & Multi-channel analyzer & Ortec \\
Detector & Contamination monitor LB122 & Berthold \\
\hline
\end{tabular}


The results from the previous analysis, which was carried out by an independent and charitable body at the National Institute for Standard in Egypt, indicated that the manufactured material does not contain any radioactive elements as shown in Appendix C.

Through the previous results, I find that $\mathrm{Na}_{2} \mathrm{SiO}_{3}$ can raise the $\mathrm{pH}$ levels and These results are consistent with Joni et al. $(2018 ; 2020)$ [13] [14] as they concluded that "Precipitated silica scale-up can be produced by optimizing the sodium silicate $\left(\mathrm{Na}_{2} \mathrm{SiO}_{3}\right)$ precursor with additional $\mathrm{HCl}$ as precipitant by direct mixing method at $\mathrm{pH} 7$ at temperature $25^{\circ} \mathrm{C}$." This, in turn, helps to raise the $\mathrm{pH}$ of adding it to the water.

The current results of our study are unique in that they raise the $\mathrm{pH}$ physically without direct interference with water, which helps protect the water from any chemical effects.

\section{Conclusion}

The $\mathrm{pH}$ value will be used as a standard to measure the properties of water. It is a measure of the concentration of hydrogen ions in a solution, which is the negative logarithm of the actual hydrogen ion concentration, meaning that the hydrogen ion concentration decreases with increasing the $\mathrm{pH}$, and that the difference of one acidity unit indicates a difference of ten times the hydrogen ion concentration. The aim of the present research was to examine a natural substance of environmental elements, extracted from silica using the thermal fusion method (developed by the authors) to increase the $\mathrm{pH}$ of water with an $80 \mathrm{~cm}$ physical field without adding any components to the water. Our research is concentrating about the physical effect on oxonium aion in any matrix and thru this field we make change into alkaline state due to the active bride which has been created between silica and sodium atoms. The solution was then assayed for increasing the $\mathrm{pH}$ value using the ASTM E70-Standard test method and Nal (TI) Scintillation detector $3 * 3$ for radiation values. The laboratory results in two independent agencies showed an increase in the $\mathrm{pH}$ rates of water within five hours to reach 8 , and this confirms the validity of the hypothesis based on this study, which is that the vital field of the material manufactured by the authors raises the $\mathrm{pH}$ rates of water from a distance. The second major finding was that the used material does not contain any radioactive elements.

\section{Acknowledgements}

The researchers extend their thanks and appreciation to Mr. Major General Sherif Fares, head of the Drinking Water Company in Sharkia Governorate, Arab Republic of Egypt, for his full support and assistance in conducting the necessary analyzes and testing. We are also pleased to thank the National Research Center and the National Institute for Standardization for conducting the necessary checks to ensure the effectiveness of the manufactured material in raising $\mathrm{pH}$ rates in water. 


\section{Conflicts of Interest}

The authors declare no conflicts of interest regarding the publication of this paper.

\section{References}

[1] Couto, R.D.R., Comin, J.J., Soares, C.R.F.S., Belli Filho, P., Benedet, L., Moraes, M.P.D., Brunetto, G. and Beber, C.L. (2013) Microphysical and Chemical Attributes of a Hapludalf Soil with Swine Manure Fertilization. Pesquisa Agropecuária Brasileira, 48, 774-782. https://doi.org/10.1590/S0100-204X2013000700010

[2] Loss, A., Lourenzi, C.R., dos Santos Junior, E., Junior, C.A.M., Benedet, L., Pereira, M.G., Comin, J.J., et al. (2017) Carbon, Nitrogen and Natural Abundance of 13C and $15 \mathrm{~N}$ in Biogenic and Physicogenic Aggregates in a Soil with 10 Years of Pig Manure Application. Soil and Tillage Research, 166, 52-58.

https://doi.org/10.1016/j.still.2016.10.007

[3] Zalvan, C.H., Hu, S., Greenberg, B. and Geliebter, J. (2017) A Comparison of Alkaline Water and Mediterranean Diet vs Proton Pump Inhibition for Treatment of Laryngopharyngeal Reflux. JAMA Otolaryngology: Head \& Neck Surgery, 143, 1023-1029. https://doi.org/10.1001/jamaoto.2017.1454

[4] Li, S.J., Lv, W.Y., Du, H., Li, Y.J., Zhang, W.B., Che, G.W. and Liu, L.X. (2019) Albumin-to-Alkaline Phosphatase Ratio as a Novel Prognostic Indicator for Patients Undergoing Minimally Invasive Lung Cancer Surgery: Propensity Score Matching Analysis Using a Prospective Database. International Journal of Surgery, 69, 32-42. https://doi.org/10.1016/j.ijsu.2019.07.008

[5] Tan, Y., Zhu, Y., Zhao, Y., Wen, L., Meng, T., Liu, X., Hu, F., et al. (2018) Mitochondrial Alkaline pH-Responsive Drug Release Mediated by Celastrol Loaded Glycolipid-Like Micelles for Cancer Therapy. Biomaterials, 154, 169-181.

https://doi.org/10.1016/j.biomaterials.2017.07.036

[6] Sun, Y., Hou, S., Song, S., Zhang, B., Ai, C., Chen, X. and Liu, N. (2018). Impact of Acidic, Water and Alkaline Extraction on Structural Features, Antioxidant Activities of Laminaria Japonica Polysaccharides. International Journal of Physical Macromolecules, 112, 985-995. https://doi.org/10.1016/j.ijbiomac.2018.02.066

[7] Vidaković, D., Krizmanić, J., Dojčinović, B.P., Pantelić, A., Gavrilović, B., Živanović, M., Ćirić, M., et al. (2019) Alkaline Soda Lake Velika Rusanda (Serbia): The First Insight into Diatom Diversity of This Extreme Saline Lake. Extremophiles, 23, 347-357. https://doi.org/10.1007/s00792-019-01088-6

[8] Korotta-Gamage, S.M. and Sathasivan, A. (2017) A Review: Potential and Challenges of Physically Activated Carbon to Remove Natural Organic Matter in Drinking Water Purification Process. Chemosphere, 167, 120-138.

https://doi.org/10.1016/j.chemosphere.2016.09.097

[9] Bora, A.J. and Dutta, R.K. (2019). Removal of Metals (Pb, Cd, Cu, Cr, Ni, and Co) from Drinking Water by Oxidation-Coagulation-Absorption at Optimized $\mathrm{pH}$. Journal of Water Process Engineering, 31, Article No. 100839. https://doi.org/10.1016/j.jwpe.2019.100839

[10] Hashim, K.S., Hussein, A.H., Zubaidi, S.L., Kot, P., Kraidi, L., Alkhaddar, R., Alwash, R., et al. (2019) Effect of Initial pH Value on the Removal of Reactive Black Dye from Water by Electrocoagulation (EC) Method. Journal of Physics. Conference Series, 1294, Article No. 072017.

https://doi.org/10.1088/1742-6596/1294/7/072017 
[11] Martins, G.B., Tarouco, F., Rosa, C.E. and Robaldo, R.B. (2017) The Utilization of Sodium Bicarbonate, Calcium Carbonate or Hydroxide in Biofloc System: Water Quality, Growth Performance and Oxidative Stress of Nile Tilapia (Oreochromis niloticus). Aquaculture, 468, 10-17.

https://doi.org/10.1016/j.aquaculture.2016.09.046

[12] Ixchel, R.H.M. and de la Luz, P.R.M. (2021) Characterization of Mine Tailings in Their Natural State and Stabilized with Cement, Focused on Construction Caracterización de residuos mineros en estado natural y estabilizados con cemento, enfocada a construcción. IngenIería InvestIgacIón y Tecnología, 22, 1-9.

https://doi.org/10.22201/fi.25940732e.2021.22.2.010

[13] Joni, I.M., Rukiah and Panatarani, C. (2020) Synthesis of Silica Particles by Precipitation Method of Sodium Silicate: Effect of Temperature, $\mathrm{pH}$ and Mixing Technique. AIP Conference Proceedings, 2219, Article No. 080018.

https://doi.org/10.1063/5.0003074

[14] Joni, I.M., Nulhakim, L., Vanitha, M. and Panatarani, C. (2018) Characteristics of Crystalline Silica (SiO2) Particles Prepared by Simple Solution Method Using Sodium Silicate $\left(\mathrm{Na}_{2} \mathrm{SiO}_{3}\right)$ Precursor. Journal of Physics. Conference Series, 1080, Article No. 012006. https://doi.org/10.1088/1742-6596/1080/1/012006 


\section{Appendix A}

\section{Whistry of Hilgher Education \& Scientficic Research \\ National Institute for Standards \\ www.nis.sci.eg}
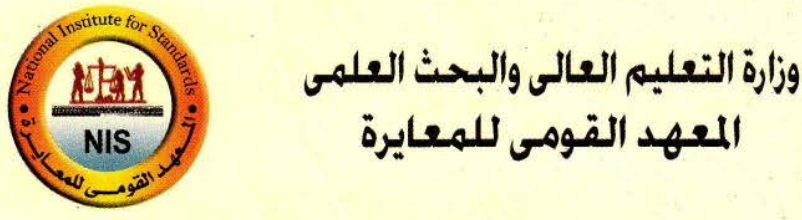

El- Sadat (Tersa) St., El Haram, Giza, Egypt - P.O.Box 136 Giza - Code 12211 - Tel. / Fax: +202 - 33867462 - NIS Tel +202 - 37401113

\section{Report No: 7/43/2021}

\section{Test Method:}

ASTM E70- Standard Test Method for $\mathrm{pH}$ of Aqueous Solutions with the Glass Electrodes. This standard was applied for calibration of our instrument: and $\mathrm{pH}$ of aqueous solution measurement.

Environmental conditions:

Temperature: $20^{\circ} \mathrm{C}$, and Humidity: $73 \%$.

\section{Test procedure:}

1. $50 \mathrm{~mL}$ of tap water were placed in beaker $100 \mathrm{~mL}$ and it was covered with stretch cover.

2. Before each measurement for $\mathrm{pH}$-value, our $\mathrm{pH}$-meter was calibrated with buffers $(4,7.02$ and $10 \mathrm{pH}$ unit).

3. The $\mathrm{pH}$ and temperature -values of tap water were measured.

4. The $100 \mathrm{~mL}$ beaker containing $50 \mathrm{~mL}$ tap water was placed on the sample according to the customer requirement.

5. $\mathrm{pH}$ and temperature-values were measured at different time intervals (each hour).

6. After each measurement the beaker was covered with stretch cover.

7. The following results were recorded (time, temperature and $\mathrm{pH}$-values).

\section{Results}

The results have been tabulated in the following table:

\begin{tabular}{|c|c|c|}
\hline Time intervals (h) & pH-value(pH unit) & $\begin{array}{c}\left.\text { Temp } \mathbf{(}^{0} \mathbf{C}\right) \text { of tap } \\
\text { water }\end{array}$ \\
\hline At the beginning & 7.5 & 18.2 \\
\hline After $1^{\text {st }} \mathrm{h}$ & 7.6 & 19.5 \\
\hline After $2^{\text {nd }} \mathrm{h}$ & 7.7 & 19.7 \\
\hline After $3^{\text {rd }} \mathrm{h}$ & 7.8 & 19.8 \\
\hline After $4^{\text {th }} \mathrm{h}$ & 7.9 & 20.3 \\
\hline After $5^{\text {th }} \mathrm{h}$ & 8 & 20.3 \\
\hline
\end{tabular}
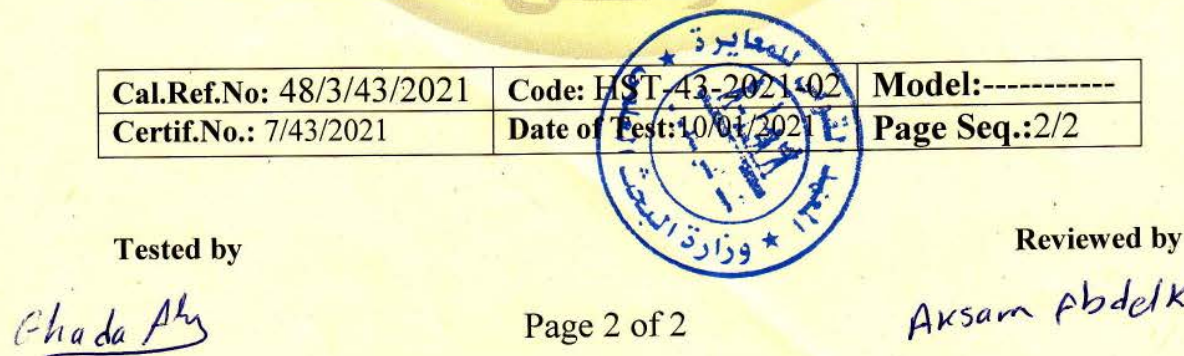

Page 2 of 2

This certificate is isued in aceosurement to recognized national stis certificate may not be reproduced other than in full by photographic process. This certificate refers only to the particular item submitted for testing. 


\section{Appendix B}
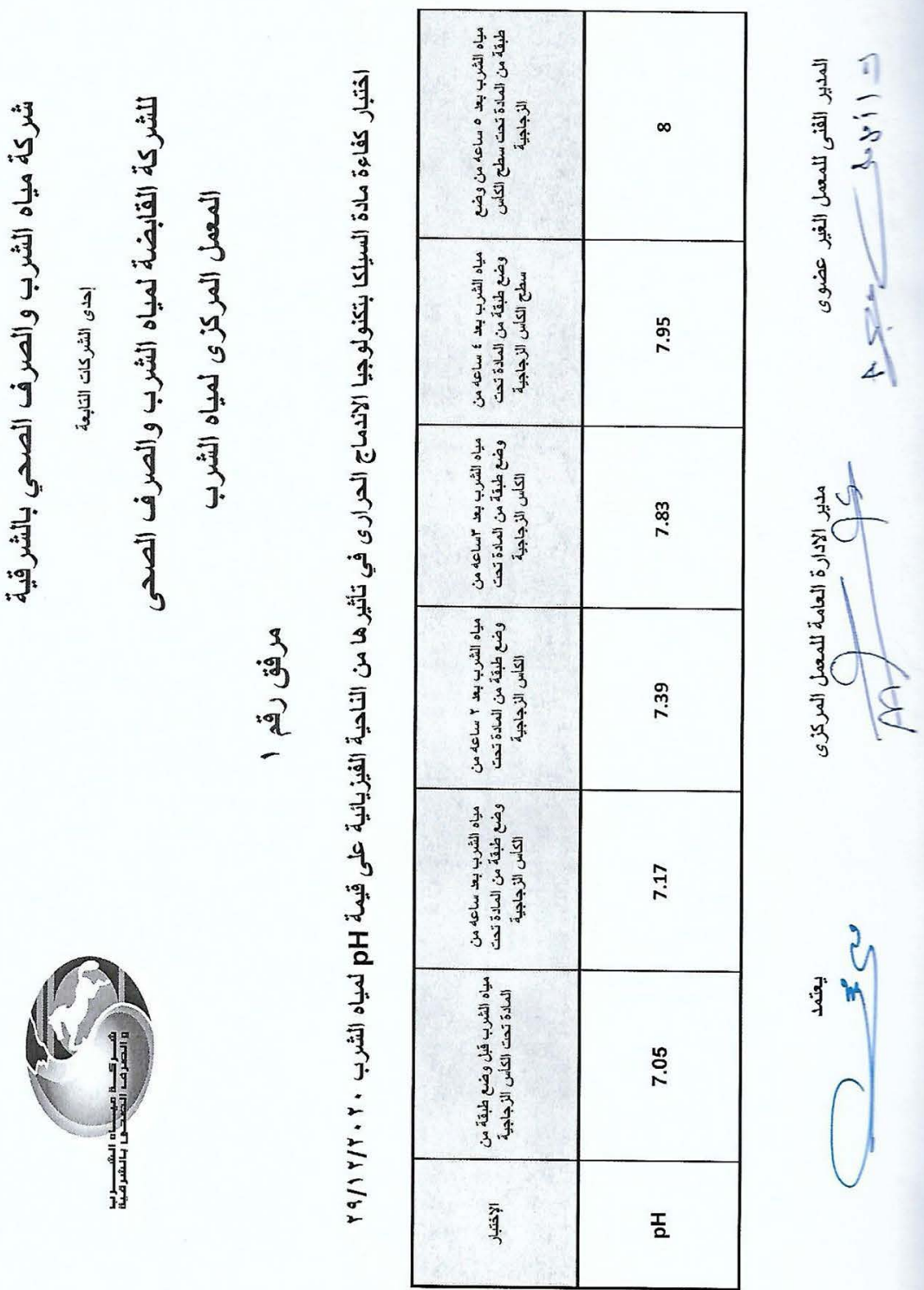


\section{Appendix C}

nistry of Higher Education

\&Scientific Research

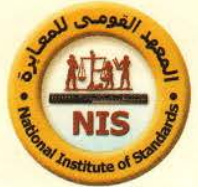

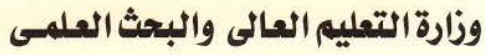

National Institute for Standards

$$
\text { المعهـلـ القومى للمعايرة }
$$

El- Sadat (Tersa) St., El Haram, Giza, Egypt - P.O.Box 136 Giza - Code 12211 - Tel. / Fax: +202 - 33867452 - NIS Tel +202 - 37401113

Standard/Reference / Major Equipment Used:

\begin{tabular}{|c|l|c|}
\hline Name & \multicolumn{1}{|c|}{ Type } & Manufacturer \\
\hline Detector & NaI(TI) Scintillation detector 3"x3” & Canberra Industries, Inc -USA. \\
\hline Analyzer & Multi-channel analyzer & ortec \\
\hline Detector & Contamination monitor LB 122 & Berthold \\
\hline
\end{tabular}

\section{$\underline{\text { Results }}$}

There is no gamma radiation and charged particle detected

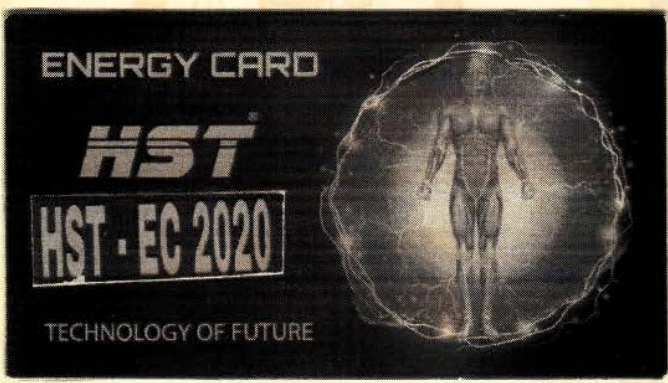

Environnemental Conditions : -

\begin{tabular}{|c|c|c|}
\hline Pressure: & Frature: $22{ }^{\circ} \mathrm{C}$ & Humidity: $50 \quad \%$ \\
\hline $\begin{array}{r}\text { Tested by: Khaled Mosta } \\
\text { Whaled Mos }\end{array}$ & Dr.,i)at & $\begin{array}{l}\text { wed by: } \\
\text { ad N.Ahmad }\end{array}$ \\
\hline Report No.: 618/31/2020 & Code: HST-EC 2020 & Model: Energy card \\
\hline Dev. Des.: Sample for radioactivity detection & Test Date: $15 / 11 / 2020$ & Page Seq.: $2 / 2$ \\
\hline
\end{tabular}

This certificate is issued in accordance with the laboratory accreditation requirements. It provides traceability of measurement to recognized

National standards, and to the units of measurement realized at the NIS or other recognized national standerds laboratories. This certificate

May not be reproduced other than in full by photographic process. This certificate refers only to the particular item submitted for testing 